\title{
What Is Democratic Theory?
}

\author{
Rikki Dean, Jean-Paul Gagnon, and Hans Asenbaum
}

What is democratic theory? The question is surprisingly infrequently posed. Indeed, the last time this precise question appears in the academic archive was exactly forty years ago, ${ }^{1}$ in James Alfred Pennock's (1979) book Democratic Political Theory. ${ }^{2}$ This is an odd discursive silence not observable in other closely aligned fields of thought such as political theory, ${ }^{3}$ political science, ${ }^{4}$ social theory, ${ }^{5}$ philosophy, ${ }^{6}$ economic theory, ${ }^{7}$ and public policy/administration ${ }^{8}$ - each of which have asked the "what is" question of themselves on regular occasion. The premise of this special issue is, therefore, to pose the question anew and break this forty-year silence.

Answering this question turns out to be rather more difficult than posing it. Pennock (1979: xvii) does not answer the question himself; he leaves that labor to posterity, only stating that "the phrase [democratic theory] is often used as though it stood for a clearly demarcated and agreed upon body of doctrine; but that is far from the case. Even the question of what topics it should include is the subject of wide disagreement." Perhaps the only thing democratic theorists could agree about democratic theory is that it is diverse, even inchoate in nature. Robert Dahl (1956: 1), for example, famously argued that "there is no democratic theory - there are only democratic theories." There are, too, a litany of rival claims, now mostly historical, to the heart of democracy, and more than twenty-two hundred adjectival descriptors of democracy have so far been documented (Gagnon 2018). In addition, many contemporary democratic theorists share a pluralist ethic concerned with avoiding an autocratic closure around what constitutes democratic theory (see, e.g., Bader 1995; Blokland 2011; Erman 2009; Held 2006; Martí 2017; Moscrop and Warren 2016; Paxton, this issue). Nevertheless, simply recognizing and embracing this diversity only gets us so far.

In this editorial we draw on the contributions to this special issue as well as the broader literature to explore the diversity of democratic theory across five planes: (1) what, (2) where, (3) who, (4) when, and (5) why. The diversity of democratic theory and, therefore, the difficulty of defining it is undoubtedly linked to the slipperiness of democracy as an object of study if only because democracy has a multitude of linguistic, geographical, and historical referents. There is no agreement even about 
whether it is a set of institutions or an ethical ideal. Therefore, asking the what, where, who, when, and why questions of democracy - and how they have been approached by democratic theorists - allows us to cast further illumination onto a dynamic field of thought, onto the question of "what", more exactly, "is democratic theory?"

\section{The What, Where, Who, When, and Why of Democracy}

\section{What?}

Describing what democracy is constitutes a key - but not the only - task for democratic theory (Dahl 1956; Deligiaouri and Suiter, this issue; Ewert and Repetti, this issue). This "what?" question in turn stipulates what it is that democratic theory should theorize. Mainstream political science, for example, gives the impression that democratic theory is settled on the question of what democracy is: the core practice of democracy is competitive elections. Democracy is about the competitive selection of elites, and thus much democratic theory is oriented toward theorizing how this process operates (e.g. Downs 1957; Schumpeter 1976), as well as the related concepts that form the bases of its legitimacy, such as accountability, representation, and legitimate coercion (e.g., respectively, Warren 2014; Mansbridge 2003, 2014). However, debates about what constitutes democratic practice lie at the heart of much contemporary democratic theory, which suggests that the mainstream political science account has missed the mark (it is precise in its claim about electoral democracy but not democracy's many other variants).

These debates are evident in the variety of models of democracy (Held 2006), usually distinguished by an adjectival descriptor focused on a specific kind of practice: representative democracy, participatory democracy, deliberative democracy, agonist democracy, and so on. Bernard Manin (1997) has, for example, demonstrated that the seemingly fixed association between democracy and elections is actually a historical oddity. For most of the last three thousand years elections were associated with oligarchy and democracy with sortition. One of the most productive veins in current democratic theory is in reimagining the role of this ancient practice in contemporary democratic institutions (see Smith 2009: ch. 3). Sortition has, for example, been particularly embraced by deliberative democrats, who, as the name suggests, are focused on deliberation rather than voting as the core practice on which democratic legitimacy is based (Dryzek 2000). The result has been a range of new democratic instruments, often called deliberative mini-publics, which use sortition to try to integrate ideal deliberative moments into democratic institutions. 
There are also democratic theorists who are altogether skeptical of the institutional focus of democratic theory. The field, it is claimed, is too focused on institution building and should instead pay greater attention to informal practices of resistance (Wagenaar 2014) and fugitive democratic moments (Schlosser, Aslam, and McIvor, this issue), when people recognize themselves as collective political actors. This view has been particularly prominent in agonist democratic theory, which has largely been skeptical of making any institutional prescriptions (Norval 2014), though this is beginning to change (Dean 2018; Lowndes and Paxton 2018). In their contribution to this issue, Schlosser, Aslam, and McIvor, for example, argue that we should adopt Sheldon Wolin's idea of fugitive democracy to creatively guide both theoretical and institutional experimentation.

The different answers to the "what?" question of democracy have obvious implications for what constitutes democratic theory. Each posits a different object for this dynamic field of inquiry. They entail theorizing democracy in different locations and focusing on different actors.

\section{Where?}

Where should democratic theorists look for democracy? Much democratic theory either implicitly or explicitly takes the politics of the nation-state as its primary object. Yet neither the scale nor domain of democracy should be regarded as settled. On the question of scale, globalization and climate change have increasingly forced democratic theorists to face questions of what a transnational or global democracy should look like (Archibugi, Koenig-Archibugi, and Marchetti 2011; Dryzek et al. 2019; Falk and Strauss 2001; Held 2012). Whereas from the opposite end, participatory democracy has always advocated the principle of subsidiarity, that democracy must begin at the lowest appropriate level (Pateman 1970). Feminist theory and parenting scholars have even demonstrated that the family should be a concern for democratic theorists (see, e.g., Pateman, this issue). Nevertheless, while democratic theory has been applied to a range of different scales, there have been relatively few attempts to fully theorize democracy as a multilevel object (Dean, Rinne, and Geissel, this issue).

Democratic theory also needs to more fully embrace domains beyond legislative politics. Whilst parliaments, political parties, and elections are an important object for democratic theory, they are not the only object, nor is it certain that they should be the main object. There are those who have argued that in advanced democracies it is public administration rather than politics that is at the vanguard of democratization 
(Boswell 2016; Dean 2017; Warren 2009). In addition, there are increasing attempts to democratize the provision of community and public services, as documented by scholars of coproduction (Durose and Richardson 2016; Nabatchi, Sancino, and Sicilia 2017). In her conversation with Graham Smith in this issue, Carole Pateman makes the argument that "employment is a vast undemocratic area of life in democracies" (p.111), thus the economy and the workplace should receive much more attention from democratic theorists than it currently does. Democratic theory can and should stretch beyond legislative politics to encompass other sites of social relations, from family and the workplace to public administration and social media discussions. Dean, Rinne, and Geissel's contribution to this issue suggests that the insight from deliberative and democratic systems approaches that democracy takes place in a wide range of "arenas" holds promise for this endeavor.

\section{Who?}

The question of who forms the demos has long been and remains a live issue in democratic theory. Much of the history of democracy is concerned with expanding demoi - "showing that the sky would not collapse if women, slaves and the poor were treated as the political and social equals of their former masters" (Keane, this issue, p.96). The adoption of the allaffected principle by many democratic theorists continues this process by forcing reflection on how political institutions may not be aligned with the relevant demos (Owen 2012) as well as how democracies must pay more attention to the interests of future generations. In this sense, vitalist accounts of democracy describe all human and non-human bodies and even inanimate objects as part of a vibrant ecology. These approaches challenge the object/subject division and therewith question a core assumption common to established democratic theories (Bennett 2010). The question is not, however, only about who constitutes the demos but also how it is constituted - whether democracy is a system for representing the fixed interests and values of preformed publics or for bringing publics into being to solve collective problems, as John Dewey (1926) argued.

Once the demos is settled, even if that is but for the duration of time it takes to resolve a problem, there remains the question of which actors take up which democratic labors. This constitutes a hot front in democratic theory and empirical political science. Deliberative and participatory democrats argue that giving citizens more opportunities to participate is both normatively desirable and instrumentally beneficial. It realizes political equality and autonomy, improves citizens' democratic capacities, and presently appears to be the only way out of the democratic 
malaise that is undermining liberal, representative states (e.g., Mayne and Geissel 2016; Neblo 2015; Pateman 1970). Whereas elite democrats argue that citizens neither want nor are capable of exercising such opportunities (e.g., Achen and Bartels 2017; Hibbing and Theiss-Morse 2002) and that democratic labors should be left to stable political parties and professional civil servants.

In his contribution to this volume, John Keane also makes the argument that democratic theory has been too narrow in its focus on who practices democracy, both historically and contemporaneously. Democratic theory has a tendency to reify a historically contingent, Anglocentric model of democracy. In addition, it neglects the extent to which supposedly universal democratic ideals were articulated in societies characterized by exclusion and oppression and can still function as weapons of domination (Schlosser, Aslam, and McIvor, this issue). Postcolonial and comparative democratic theory are gradually challenging this dominance but are significantly hampered by both the political economy of the Academy and that the English language is, without justification, democratic theory's hegemonic mode of expression.

\section{When?}

Democracy is an ancient idea; therefore, much democratic theory is a form of intellectual history with a strong connection to the past. John Keane sets out a case for the importance of the historical imagination in democratic theory in this issue. He argues for the importance of knowing democracy's past - the paths it has trodden, the wrong turns and dead -ends - for interpreting the present and future. We already mentioned above how the rediscovery of sortition as a democratic practice is challenging the idea of the vote as the total democratic institution, an erroneous condition that Pierre Rosanvallon (2008) once called out.

Keane also stresses the importance of recognizing that democracy is rooted in time - that it is a historically contingent phenomenon rather than a transcendental abstract essence. Whilst Keane directs this critique at the triumphal teleology of the post-Communist period, when the liberal democratic future was supposedly historically assured, much current democratic scholarship seriously engages with this historical contingency of present democracies (see, e.g., Yves Schemeil's (2000) articulation of "democracy before democracy"). The democratization field has for a long time been concerned with how democracy takes root in previously nondemocratic regimes and the conditions under which it can blossom. Current events in a number of established democracies means this democratization scholarship has now been joined by a new and 
more pessimistic concern with how democracies fail (e.g., Bermeo 2016; Levitsky and Ziblatt 2018; Runciman 2018). The lifecycle of present-day democracy is thus a vibrant domain of democratic theory.

The future, however, appears to be more of a niche concern within democratic theory, and there is little explanation for why this seems the case. For some, like Jacques Derrida and Fred Dallmayr, democracy is the future. Democracy is never in the present but is always "to come" - a horizon to be perpetually struggled toward (see Dallmayr 2017). While the field of democratic innovation has been quite successful in proposing new institutional forms for democratic decision making, democratic theory has said surprisingly little about how democracy should adjust to the great challenges facing humanity in the future. Increasingly representative democracy, for example, flourished during a Holocentric period of fossil-fuel-based economic expansion (Dryzek and Pickering 2019); green democracy, which challenges this link, remains on the margins of the field. Moreover, as James Wong (2016) has highlighted, the relationship between democracy and environmental sustainability is dilemmatic at heart. Similarly, democratic theory has been slow to respond to the digital transformation of society (Asenbaum 2019), so that, for instance, democratic theorists have provided little vision for what a democratic "smart city" would look like. The task has been left to technologists and innovative city administrations such as Barcelona's and Toronto's. Democratic theory thus currently lacks a broad mobilizing narrative for the future, something akin to the demand for universal suffrage for the twenty-first century.

\section{Why?}

"Why democracy?" is arguably the preeminent question in democratic theory. It is where the field most resembles normative political theory and is likely for most scholars the first association invoked by the term "democratic theory." Purely normative approaches to justifying democracy argue that it is entailed by fundamental principles such as autonomy, equality and freedom. Democratic institutions are therefore derived from these foundational principles as the only legitimate instantiation of government (e.g., Held 2006: ch. 10). However, others take a more instrumental approach to justification. Dahl (2000: 45) answers the "why democracy?" question with ten "desirable consequences" of democratic governance: (1) avoiding tyranny, (2) essential rights, (3) general freedoms, (4) self-determination, (5) moral autonomy, (6) human development, (7) protecting essential personal interests, (8) political equality, (9) peace seeking, and (10) prosperity. 
A recent development in this regard are epistemic defenses of democracy. Reversing the critique of democracy from time-immemorial that its decisions are short-sighted and ill-informed, epistemic democrats have argued that democracy is valuable because it produces better and more just decisions (e.g., Estlund 2008; Landemore 2017). Whether normative or instrumental reasons provide sufficient justification for democracy (Anderson 2008) or whether it is even possible to develop procedure-independent justifications for democracy (Peter 2008) remain live questions. As such, the "why democracy" question continues to be an important focus among many democratic theorists.

\section{What, Then, Is Democratic Theory?}

Our discussion of the what, where, who, when, and why of democracy has a number of implications for the question of "What is democratic theory?" One obvious insight is that democratic theory is a field characterized by its multidisciplinarity. It is not simply "a subfield of political theory," as suggested by Laurence (2017: 1) and, of course, by Pennock's title of Democratic Political Theory. Democratic theory cuts across Warren's (1989) distinction between political theory and political philosophy - the former concerned with explanatory theories, the latter oriented to questions of ontology, epistemology, and normativity. Democratic theory encompasses all of these aspects.

Neither can democratic theory be reduced to a "new field of political science" (Dahl 1956: xi; Mansbridge 2014). Our discussion highlighted how democratic theories are also produced in the policy sciences as well as in relation to workplace management and the family - essentially any place that agents, both human and non-human, relate to one another.

It was noted how democratic theory is also the subject of history. There are many more fields that could be added; for example, archaeologists contribute to democracy's historiography by teasing out the social and political structures of, say, lost republics such as Tlaxcallan (Fargher et al. 2011), and anthropological ethnography of communities draw attention to different forms of collective decision making such as campfire democracy (Glassman 2017). Much of the strength of the field comes from this multidisciplinarity and its ability to connect across disciplines - whether that is through normative theory and empirical political science (Fleuss and Schaal, this issue) or political theory and public policy (Paxton, this issue). However, we wager that democratic theory's future is likely to depend on how well it can connect to the environmental 
sciences (e.g., through the further rapprochement of democratic theories and nonhumans) as well as science and technology studies.

The discussion also made apparent the diversity of what democratic theory does. It documents the ideals, actors, and institutions of democracies past and present. It produces explanatory theories about how these democracies came into being or why they disappeared. It elaborates ethical ideals of how people can act collectively as well as articulates the practices by which such ideals can be realized. It develops proposals for new forms of institutions. It provides guiding visions of the future. This is, indeed, a subject taken up in more detail by Michael Saward's and Dannica Fleuss and Gary Shaal's articles in this special issue. We are sympathetic to their pragmatist orientation to democratic theory; however, we think that what democratic theory does is broader than simply providing normatively informed "institutional devices as a means for solving coordination problems" (Fleuss and Schaal: p14).

Take, for instance, the "model wars" that have characterized much democratic theory - a kind of ideological struggle to define a best form of democracy situated around a particular form of practice (as critiqued by Warren 2017; Saward, this volume). The struggle is evident in battles over representative democracy vs. direct democracy, participatory democracy vs. elite democracy, and agonist democracy vs. deliberative democracy. While it is welcome that democratic theory is going beyond these model wars to theorize through multiple lenses and adopt system-, design-, and problem-oriented thinking (see respectively: Dean, Rinne and Geissel, this issue; Saward, this issue; Warren 2017), there is still value in the struggle between theories, as it clarifies the different ideals invoked by the different theories and their connection to different forms of practice. The "model wars" also push the boundaries of what counts as democratic. There are, too, attempts to reconcile the struggle between models, as can be seen, for instance, not only in the combination of deliberative and agonistic perspectives (cf. Khan 2013; Knops 2007) but also in the Irish Citizens' Assembly, which combined elements of representative and direct democracy through a deliberative procedure (Farrell, Suiter, and Harris 2019).

Perhaps the only - but still necessarily imperfect - metaphor that may work for democratic theory given our earlier recognitions is a more overlapping and fuzzy version of Dahl's vineyard. Picture hillsides covered in rows of vines: fruits of countless varieties are being tended by people with different knowledges, approaches, and methods. Some people know each other, others do not, and some are rather famous for the good wine they make or have made (or are famous for commenting on the wine made by others!). There are camps, rivalries, alliances, and cross-pollination in the 
pursuit of making a new fruit to satisfy changing tastes, needs, and conditions. Some rows of vines are not so easily distinguishable from others, and some fruits, strange as they are, lead to debate as to whether they should be in the vineyard in the first place and whether any wine could (or should) possibly be made from their cultivation. And why are these many people here, laboring alongside each other or doing so indifferently to one another, caring for these many varieties of fruits and (sometimes) making wine from them? Well, the answers are seemingly endless. What we do know is that some people in the vineyard share a set of common concerns for this thing we have, over centuries, come to term "democracy": for some, democracy is the equalizer; for others it is the justice maker, the rules keeper, the rights protector, the quality of life raiser, the peacemaker, the redistributor, the responsive one, or all of these ideal virtues or none of them, and it is therefore for something else altogether. But this vineyard large, complex, surprising, nebulous, and sometimes contradictory as it is - exists (again for some, not all) for two small reasons: to counter tyranny and find healing correctives to violence (the latter includes a strong focus on inequality that certain theorists consider to be a form of violence; see Giroux 2013: 227). It makes sense that people would find their own ways to oppose these un- and anti-democratic forces in whatever circumstances they are or were found across time and space and language, and it also makes sense that a variety of democratic designs for solving problems would emerge to contest potential autocratic solutions. But that pragmatic, rather functionalist, and necessarily partial observation (for there are simply too many fruits and laborers for us to know) skirts another reason that some people in the vineyard certainly share: they are working and will not stop doing so for the love of democracy (or one or more of its synonyms) for reasons of sheer intellectual curiosity and the immense joy one receives when learning about their chosen subject. Some in the vineyard are not problem bound, and although they are driven by other duties and desires, this still does not discount the fact that their wine, should they decide to make some, can also be traded and used as libations here or there to help soothe the democratic troubles of our world.

The field of democratic theory is, then, a vibrant community of thinkers and ideas - both dead and alive, old and new, known and forgotten, mainstream and marginal, accepted and contested. It is a multitemporal and multispatial community of overlapping and contradictory concerns that breathes life into countless democratic practices; offers opposition to antidemocracy wheresoever it is to be found; seeks the nonviolent resolution of problems; longs for open, recurring, challengeable, decision making; dreams about life that's somehow better for us all (including nonhumans); and so much, much more. 
Despite the existing diversity in democratic theory, there remains considerable scope for further methodological innovation. Saward, for example, provides some guidance in his article in this issue, proposing that a core of democratic theory (as he has observed in the archive) is surrounded by four concentric circles, each increasingly radical in its implication for how democratic theory is conducted. The first two circles chime with much of what we have already expressed and suggest an integration with a range of cognate academic fields. In the third circle Saward advocates for nonacademic forms of writing and speech, such as political biographies and fiction. The fourth circle asks us to consider the importance of nonwritten artworks - such as performance, painting, and sculpture - and their capacity to induce reflection on democratic concepts and issues. This is one area in which established democracies could learn from practices in the Global South, where participatory theater, for instance, is an established technique for helping communities think through how to better live together (e.g., Sloman 2012). We would add that new digital technologies also provide opportunities for prototyping democratic theories in online worlds. There is also an opportunity to democratize democratic theory. Academic democratic theory has, as yet, failed to open itself up in ways that have become common in the policy sciences and development studies, where participatory research methods have become relatively common and scholars have increasingly coproduced knowledge with other stakeholders. Democratic theorists, in contrast, have been strangely reticent to engage the demos in theorizing about democracy. The next frontier for democratic theory may thusly be its coproduction.

Rikki Dean is a postdoctoral fellow in the Democratic Innovations Research Unit, Goethe-University Frankfurt. His research interests encompass democratic theory, public administration theory, participatory policy making, process preferences, and social exclusion. ORCID: 0000-0001-5381-4532

Jean-Paul Gagnon is an assistant professor in democracy studies at the University of Canberra and faculty affiliate of the Centre for Deliberative Democracy and Global Governance. Jean-Paul edits the Berghahn (Oxford/New York) journal Democratic Theory and the Palgrave Macmillan book series on The Theories, Concepts and Practices of Democracy, and he directs the fledgling Foundation for the Philosophy of Democracy. ORCID: 0000-0003-3234-7319

Hans Asenbaum is a research fellow at the Institute for Advanced Sustainability Studies (IASS) in Potsdam and a PhD researcher at the Centre for the Study of Democracy at the University of Westminster in London. His research interests include identity and inclusion in new participatory spaces, digital politics, and theoretical debates on radical democracy. ORCID: 0000-0001-9780-9735 


\section{DACKNOWLEDGMENTS}

The authors would like to thank the Participatory and Deliberative Democracy Specialist Group of the Political Studies Association, Participedia, the Centre for the Study of Democracy, King's College London, and the University of Westminster for hosting the conference "Participatory Spaces in Perspective," September 5-7, 2018, which was where the idea for this special issue was first formulated.

\section{NOTES}

1. We ran the phrase "what is democratic theory" through: (1) Microsoft Academic, (2) Google Scholar, (3) Google Books, (4) Jstor, (5) Academic Search Ultimate, (6) Web of Science Core Collection, (7) Scopus, (8) Directory of Open Access Journals (DOAJ). Results, other than Pennock (1979), were nil.

2. We recognize that our search is limited by the English language.

3. See, for example, Catlin (1957), Warren (1989), Dallmayr (2004), Tully (2002), White and Moon (2004), Gunnell (2010), and Hoffman and Graham (2015).

4. See, for example, Goodnow (1905), Dahl (1955), Baoxu and Chu (1984), Boyer (1990), Ollman (2010), and Rehfeld (2010).

5. See, for example, Willis et al. (2007), Lemert (2009), Rees (2011).

6. See, for example, Hildebrand (1960), Smith and Protevi (2018), Priest (2006).

7. See, for example, Bennet (1968), Thaler (1992), Bellofiore (1994).

8. See, for example, Nutting (1935), Jenkins (1993: 30), Stillman (1997), Rudder (2008: 906), Menzel and White (2011: x), Raadschelders (2011).

\section{REFERENCES}

Achen, Christopher, and Larry Bartels. 2017. Democracy for Realists: Why Elections Do Not Produce Responsive Government. Princeton, NJ: Princeton University Press.

Anderson, Elizabeth. 2008. "An Epistemic Defense of Democracy: David Estlund's Democratic Authority.” Episteme 5 (1): 129-139. https:/|doi.org/10.3366| E1742360008000270.

Archibugi, Daniele, Mathias Koenig-Archibugi, and Raffaele Marchetti, eds. 2011. Global Democracy: Normative and Empirical Perspectives. Cambridge, New York: Cambridge University Press.

Asenbaum, Hans. 2019. "Rethinking Digital Democracy: From the Disembodied Discursive Self to New Materialist Corporealities." Communication Theory, in print.

Bader, Veit. 1995. "Citizenship and Exclusion: Radical Democracy, Community, and Justice. Or, What Is Wrong with Communitarianism?" Political Theory 23 (2): 211-246.

Baoxu, Zhao, and David Chu. 1984. "The Revival of Political Science in China." PS: Political Science \& Politics 17 (4): 745-757.

Bellofiore, Riccardo. 1994. "History of Economic Thought as a Problem." History of Economic Ideas 2 (2): 124-146. 
Bennett, Jane. 2010. Vibrant Matter: A Political Ecology of Things. Durham/London: Duke University Press.

Bennett, John W. 1968. "Reciprocal Economic Exchanges among North American Agricultural Operators.” Southwestern Journal of Anthropology 24 (3): 276-309.

Bermeo, Nancy. 2016. “On Democratic Backsliding.” Journal of Democracy 27 (1): 5-19. https://doi.org/10.1353/jod.2016.0012.

Blokland, Hans. 2011. Pluralism, Democracy and Political Knowledge: Robert A. Dahl and His Critics on Modern Politics. London: Routledge.

Boswell, John. 2016. "Deliberating Downstream: Countering Democratic Distortions in the Policy Process.” Perspectives on Politics 14 (3): 724-737. http://dx.doi. org/10.1017/S1537592716001146.

Boyer, William W. 1990. "Political Science and the $21^{\text {st }}$ Century: From Government to Governance.” PS: Political Science and Politics, 23 (1): 50-54.

Catlin, George. 1957. “Political Theory:What Is It?” Political Science Quarterly72 (1):1-29.

Dahl, Robert A. 1955. “The Science of Politics: New and Old.” World Politics 7 (3): 479-489.

Dahl, Robert A. 1956. A Preface to Democratic Theory. Chicago: University of Chicago Press.

Dahl, Robert A. 2000. On Democracy. New Haven, CT: Yale University Press.

Dallmayr, Fred. 2004. "Beyond Monologue: For a Comparative Political Theory." Perspectives on Politics 2 (2): 249-257.

Dallmayr, Fred. 2017. Democracy to Come: Politics as Relational Praxis. Oxford: Oxford University Press.

Dean, Rikki J. 2017. "Beyond Radicalism and Resignation: The Competing Logics for Public Participation in Policy Decisions.” Policy and Politics 45 (2): 213-230. https://doi.org/10.1332/030557316X14531466517034.

Dean, Rikki. 2018. "Counter-Governance: Citizen Participation Beyond Collaboration.” Politics and Governance 6 (1): 180-188. https://doi.org/10.17645/pag. v6i1.1221.

Dewey, John. 1926 (2012). The Public and Its Problems: An Essay in Political Inquiry. University Park: Penn State University Press.

Downs, Anthony. 1957. An Economic Theory of Democracy. Harper \& Row.

Dryzek, John S. 2000. Deliberative Democracy and Beyond : Liberals, Critics, Contestations. Oxford: Oxford University Press.

Dryzek, John, and Jonathan Pickering. 2019. The Politics of the Anthropocene. Oxford: Oxford University Press.

Dryzek, John S., Quinlan Bowman, Jonathan Kuyper, Jonathan Pickering, Jensen Sass, and Hayley Stevenson. 2019. Deliberative Global Governance, 1st ed. Cambridge: Cambridge University Press. https://doi.org/10.1017/9781108762922.

Durose, Catherine, and Liz Richardson. 2016. Designing Public Policy for Co-Production: Theory, Practice and Change. Bristol: Policy Press.

Erman, Eva. 2009. "What Is Wrong with Agonistic Pluralism? Reflections on Conflict in Democratic Theory." Philosophy and Social Criticism 35 (9): 1039-1062.

Estlund, David. 2008. Democratic Authority: A Philosophical Framework. Princeton, NJ: Princeton University Press. 
Falk, Richard, and Andrew Strauss. 2001. "Toward Global Parliament Bridging the Globalization Gap.” Foreign Affairs 80: 212-220.

Fargher, Lane F., Richard E. Blanton, Verenice Y. Heredia Espinoza, John Millhauser, Nezahualcoyotl Xiuhtecutli, and Lisa Overholtzer. 2011. "Tlaxcallan: The Archaeology of an Ancient Republic in the New World." Antiquity 85 (327): 172-186.

Farrell, David M., Jane Suiter, and Clodagh Harris. 2019. “'Systematizing' Constitutional Deliberation: The 2016-18 Citizens’ Assembly in Ireland.” Irish Political Studies 34 (1): 113-123. https://doi.org/10.1080/07907184.2018.1534832.

Gagnon, Jean-Paul. 2018. “2,234 Descriptions of Democracy: An Update to Democracy's Ontological Pluralism.” Democratic Theory 5 (1): 92-113.

Giroux, Henry A. 2013. "Resisting Youth and the Crushing State Violence of Neoliberalism." In A Critical Youth Studies for the $21^{\text {st }}$ Century, ed. Peter Kelly and Annelies Kamp. 223-241. Leiden: Brill.

Glassman, Ronald M. 2017. The Origins of Democracy in Tribes, City-States and Nation-States, vol. 1. New York: Springer.

Goodnow, Frank J. 1905. "The Work of the American Political Science Association." Proceedings of the American Political Science Association 1: 35-46.

Gunnell, John G. 2010. "Professing Political Theory.” Political Research Quarterly 63 (3): 674-679.

Held, David. 2006. Models of Democracy, 3rd ed. Stanford, CA: Stanford University Press.

Held, David. 2012. Democracy and the Global Order: From the Modern State to Cosmopolitan Governance. Cambridge: Polity Press.

Hibbing, John R., and Elizabeth Theiss-Morse. 2002. Stealth Democracy: Americans' Beliefs About How Government Should Work. Cambridge, New York: Cambridge University Press.

Hildebrand, Dietrich Von. 1960. What Is Philosophy? Milwaukee: Bruce Publishing Company.

Hoffman, John, and Paul Graham. 2015. Introduction to Political Theory. London: Routledge.

Jenkins, Bill. 1993. "Policy Analysis: Models and Approaches." In Policy Process: A Reader, ed. Michael Hill, 30-40. London: Routledge.

Khan, Gushan. 2013. "Critical Republicanism: Jürgen Habermas and Chantal Mouffe.” Contemporary Political Theory 12 (4): 318-337. doi: 10.1057/cpt.2013.3.

Knops, Andrew. 2007. "Agonism as Deliberation: On Mouffe's Theory of Democracy.” Journal of Political Philosophy 15 (1): 115-126.

Landemore, Helen. 2017. Democratic Reason: Politics, Collective Intelligence and the Rule of the Many. Princeton, NJ: Princeton University Press.

Laurence, Michael. 2017. “Democratic Theory.” Oxford Bibliographies. www.oxfordbibliographies.com/view/document/obo-9780199756223/obo-97801997562230162.xml.

Lemert, Charles. 2009. “What Is Social Theory?” In The Routledge Companion to Social Theory, ed. Anthony Elliott, pp. 3-18. London: Routledge.

Levitsky, Steven, and Daniel Ziblatt. 2018. How Democracies Die, 1st edition. New York: Crown. 
Lowndes, Vivien, and Marie Paxton. 2018. "Can Agonism Be Institutionalised? Can Institutions Be Agonised? Prospects for Democratic Design.” British Journal of Politics and International Relations 20 (3): 693-710. https://doi. org/10.1177/1369148118784756.

Manin, Bernard. 1997. The Principles of Representative Government. Themes in the Social Sciences. Cambridge: Cambridge University Press. http://dx.doi. org/10.1017/CBO9780511659935.

Mansbridge, Jane. 2003. "Rethinking Representation.” American Political Science Review 97 (4): 515-528. https://doi.org/10.1017/S0003055403000856.

Mansbridge, Jane. 2014. “What Is Political Science For?” Perspectives on Politics 12 (1): 8-17. https://doi.org/10.1017/S153759271300368X.

Mayne, Quinton, and Brigitte Geissel. 2016. "Putting the Demos Back into the Concept of Democratic Quality.” International Political Science Review 37 (5): 634-644. https://doi.org/10.1177/0192512115616269.

Martí, José Luis. 2017. "Pluralism and Consensus in Deliberative Democ-racy." Critical Review of International Social and Political Philosophy 20 (5): 556-579.

Menzel, Donald C., and Harvey L. White, eds. 2011. The State of Public Administration: Issues, Challenges and Opportunities. London: M. E. Sharpe.

Moscrop, David R. H., and Mark E. Warren. 2016. "When Is Deliberation Democratic?” Journal of Public Deliberation 12 (2): article 4.

Nabatchi, Tina, Alessandro Sancino, and Mariafrancesca Sicilia. 2017. "Varieties of Participation in Public Services: The Who, When, and What of Coproduction.” Public Administration Review 77 (5): 766-776. https://doi.org/10.1111/puar.12765.

Neblo, Michael A. 2015. Deliberative Democracy between Theory and Practice. Cambridge: Cambridge University Press.

Norval, Aletta J. 2014. "Deliberative, Agonistic and Aversive Grammars of Democracy: The Question of Criteria.” In Practices of Freedom, ed. Steven Griggs, Aletta J. Norval, and Hendrik Wagenaar, 60-84. Cambridge: Cambridge University Press. https://doi.org/10.1017/CBO9781107296954.003.

Nutting, Charles B. 1935. "Suggested Limitations of the Public Policy Doctrine." Minnesota Law Review 19: 196-209.

Ollman, Bertell. 2010. "What Is Political Science? What Should It Be?” New Political Science 22 (4): 553-562.

Owen, David. 2012. “Constituting the Polity, Constituting the Demos: On the Place of the All Affected Interests Principle in Democratic Theory and in Resolving the Democratic Boundary Problem.” Ethics and Global Politics 5 (3): 129-152. https://doi.org/10.3402/egp.v5i3.18617.

Pateman, Carole. 1970. Participation and Democratic Theory. Cambridge: Cambridge University Press.

Pennock, James Alfred. 1979. Democratic Political Theory. Princeton, NJ: Princeton University Press.

Peter, Fabienne. 2008. "Pure Epistemic Proceduralism.” Episteme 5 (1): 33-55. https://doi.org/10.3366/E1742360008000221.

Priest, Graham. 2006. “What Is Philosophy?” Philosophy 81 (2): 189-207. 
Raadschelders, Jos C. N. 2011. "The Future of the Study of Public Administration: Embedding Research Object and Methodology in Epistemology and Ontology.” Public Administration Review 71 (6): 916-924.

Rees, Tobias. 2011. "As If 'Theory' Is the Only Form of Thinking, and 'Social Theory' the Only Form of Critique: Thoughts on an Anthropology Beyond BST (Beyond Society and Theory)." Dialectical Anthropology 35. https://link.springer. com/article/10.1007/s10624-011-9248-4\#citeas.

Rehfeld,Andrew.2010. “OffensivePoliticalTheory.” PerspectivesonPolitics 8(2):465-486. Rosanvallon, Pierre. 2008. Counter-Democracy: Politics in an Age of Distrust. Cambridge: Cambridge University Press.

Rudder, Catherine E. 2008. "Private Governance as Public Policy: A Paradigmatic Shift." Journal of Politics 70 (4): 899-913.

Runciman, David. 2018. How Democracy Ends. New York: Basic Books.

Schemeil, Yves. 2000. “Democracy Before Democracy.” International Political Science Review 21 (2): 99-120.

Schumpeter, Joseph A. 1976. Capitalism, Socialism and Democracy. 5th ed. Routledge.

Sloman, Annie. 2012. "Using Participatory Theatre in International Community Development.” Community Development Journal 47 (1): 42-57. https://doi. org/10.1093/cdj/bsq059.

Smith, Graham. 2009. Democratic Innovations. Theories of Institutional Design. Cambridge University Press. http://dx.doi.org/10.1017/CBO9780511609848.

Smith, Daniel and John Protevi. 2018. “Gilles Deleuze”. Stanford Encyclopedia of Democracy. https://plato.stanford.edu/entries/deleuze/\#Wha

Stillman, Richard J. 1997. “American vs. European Public Administration: Does Public Administration Make the Modern State, or Does the State Make Public Administration?” Public Administration Review 57 (4): 332-338.

Thaler, Richard H. 1992. The Winner's Curse: Paradoxes and Anomalies of Economic Life. New York: Free Press.

Tully, James. 2002. "Political Philosophy as a Critical Activity.” Political Theory 30 (4): 533-555.

Wagenaar, Hendrik. 2014. "The Agonistic Experience: Informality, Hegemony and the Prospects for Democratic Governance.” In Practices of Freedom, ed. Steven Griggs, Aletta J. Norval, and Hendrik Wagenaar, 217-248. Cambridge: Cambridge University Press. https://doi.org/10.1017/CBO9781107296954.010.

Warren, Mark E. 1989. “What Is Political Theory/Philosophy?” PS: Political Science and Politics 22 (3): 606-612.

Warren, Mark. 2009. “Governance-Driven Democratization.” Critical Policy Studies 3 (1): 3-13. https://doi.org/10.1080/19460170903158040.

Warren, Mark. 2014. “Accountability and Democracy.” In The Oxford Handbook of Public Accountability, ed. Mark Bovens, Robert E. Goodin, and Thomas Schillemans. Oxford University Press. www.oxfordhandbooks.com/view/10.1093/ oxfordhb/9780199641253.001.0001/oxfordhb-9780199641253-e-018.

Warren, Mark E. 2017. “A Problem-Based Approach to Democratic Theory.” American Political Science Review 111 (1): 39-53. 
Willis, Karen, Jeanne Daly, Michelle Kealy, Rhonda Small, Glenda Koutroulis, Julie Green, Lisa Gibbs, and Samantha Thomas. 2007. “The Essential Role of Social Theory in Qualitative Public Health Research.” Australian and New Zealand Journal of Public Health 31 (5): 438-443.

White, Stephen K., and J Donald Moon, eds. 2004. What Is Political Theory? London: Sage.

Wong, James K. 2016. “A Dilemma of Green Democracy.” Political Studies 64 (1 suppl): 136-155. https://doi.org/10.1111/1467-9248.12189. 